\title{
PEMBUATAN PAVING BLOCK BERBASIS SEMEN POLIMER DENGAN LIMBAH PADAT GRIT SEBAGAI SUBSTITUSI PASIR DAN PEREKAT POLIVINYL ALKOHOL (PVA)
}

\author{
Juaksa Manurung \\ juaksamanurung@gmail.com
}

\begin{abstract}
ABSTRAK.
Paving block dalam penelitian ini adalah campuran dari material pasir, grit, semen,Polivinyl Alkohol dan air. Variabel pada paving block ini adalah komposisi grit terhadap pasir : $0: 100 ; 10: 90 ; 20: 80$; $30: 70 ; 40: 60 ; 50: 50 ; 60: 40 ; 70: 30 ; 80: 20 ; 90: 10 ; 100: 0$ (\%volume). Adapun tujuan penelitian adalah pemanfaatan limbah industri bubur kertas yaitu grit sebagai substitusi pasir dan penggunaan Polivinyl Alkohol sebagai perekat pada pembuatan paving block. Semen sebagai penguat dan PVA sebagai perekat adalah konstan. Sampel ujiberbentuk kubus $5 \mathrm{~cm} \times 5 \mathrm{~cm}$ x $5 \mathrm{~cm}$ dan balok 12 $\mathrm{cm} \times 3 \mathrm{~cm} \times 3 \mathrm{~cm}$. Dari hasil penelitian bahwa paving blockdengan variasi komposisi terbaik adalah $50 \%$ (volume) grit dan50\%(volume)pasir.Pada komposisi tersebut diperoleh paving block tanpa penggunaan PVA sebagai berikut : densitas $=1,61 \mathrm{~g} / \mathrm{cm} 3$, penyerapan air $=8,86 \%$, kuat tekan $=$ $12,60 \mathrm{MPa}$, kuat pukul =1,26 MPa,kuat patah $=0,133 \mathrm{MPa}$. Dan paving block dengan menggunakan PVA adalah sebagai berikut : densitas $=1,54 \mathrm{~g} / \mathrm{cm} 3$, penyerapan air $=5,43 \%$, kuat tekan $=13,40$ $\mathrm{MPa}$, kuat pukul $=2,15 \mathrm{MPa}$, kuat patah $=0,0278 \mathrm{MPa}$.Hasil pengamatan dengan menggunakan mikroskop optik terlihat jelas butiran grit berwarna putih kekuningan dan butiran tersebut terlihat semakin besar setealahsampel direndam dalam air.
\end{abstract}

Kata kunci : Paving block, grit, semen, pasir, PVA, pengadukan manual.

\section{PENDAHULUAN}

Limbah pada umumnya adalah merupakan sisa olahan suatu pabrik atau industri. Bentuk limbah pada dasarnya cair atau padat yang jumlahnya cukup besar tergantung pada jenis industrinya. Limbah selalu diartikan sebagai sumber pencemaran yang dapat mengganggu aktivitas maupun lingkungan yang berdampak negatif terhadap kesehatan masyarakat di lingkungan pabrik maupun kawasan sekitarnya.Limbah padat pulp .Limbah padat pulp adalah limbah yang diperoleh dari sisa-sisa pengolahan industri pulp. Limbah itu berupa grit, dreg, sludge, bio sludge. Menurut pantauan dilapangan, jumlah limbah padat pulp di PT. TPL Porsea
Tobasa mencapai 7 ton perharinya. Data di lapangan menunjukkan jumlah ini cukup besar sehingga timbul pemikiran bagaimana caranya mengolah limbah ini menjadi material baru yang berguna untuk meningkatkan ekonomi masyarakat. Polivinyl Alkohol (PVA) adalah bahan polimer yang merupakan serat sintesis karena mengandung sellulosa. Bahan ini dipakai sebagai perekat karena sangat baik daya rekatnya, sebagai pengubah sifat serat dan penganji benang untuk mencegah keriting dan patah (Malcohn R. S, 2001).Paving block merupakan produk bahan bangunan 
Pembuatan Paving Block Berbasis Semen Polimer Dengan Limbah Padat Grit Sebagai Substitusi Pasir Dan Perekat Polivinyl Alkohol (Pva)

dari semen yang digunakan sebagai salah satu alternatif penutup atau pengerasan permukaan tanah. Berdasarkan SNI 03-06911996 paving block adalah campuran dari semen Portland, agregat halus (pasir) dan air dengan standard mutu K $125(125 \mathrm{~kg} / \mathrm{cm} 2)$ dengan perbandingan semen $:$ pasir $:$ FAS $=1$ : 3 : 0,6. Dalam penelitian pembuatan paving block ini penulis ingin mengkomposisikan limbah padat grit sebagai pengisi subsitusi pasir untuk pemanfaatan limbah padat grit dan mengkomposisikan Polivinyl Alkohol (PVA) dengan tujuan yang berbasis semen polimer. Dimana akan lebih sedikit menyerap air sehingga akan mengurangi perkembangbiakan jamur dan lumut di atasnya, disamping itu akan lebih tahan terhadap asam karena sifat PVA itu sendiri.

\section{Metode Penelitian}

Penelitian ini menggunakan Bahan Baku dan Peralatan, antara lain :

\section{Bahan Baku yang dipergunakan adalah :}

1.Pasir : diperoleh dari Binjai

2.Limbah padat grit : diperoleh dari PT.TPL

Porsea Tobasa

3.Semen type I ( Portland cement)

4.Air

\section{Polivinnyl Alkohol ( PVA)}

\section{Perlatan yang digunakan antara lain :}

1.Satu set ayakan berukuran ( 38,1 mm ; 19,1 $\mathrm{mm} ; 9,52 \mathrm{~mm} ; 4,76 \mathrm{~mm} ; 2,38 \mathrm{~mm} ; 1,19$ $\mathrm{mm} ; 8,6 \mathrm{~mm} ; 0,3 \mathrm{~mm} ; 0,15 \mathrm{~mm}$ ) yang dipergunakan untuk menyaring agregat pasir dan grit.

2. Neraca digital untuk menimbang bahan.

3. Oven untuk mengeringkan bahan.

4. Cetakan benda uji (sampel).

a. Kubus mortar dengan ukuran $5 \mathrm{~cm}$ x $5 \mathrm{~cm}$ $\mathrm{x} 5 \mathrm{~cm}$ untuk pengujian densitas; penyerapan air dan kuat tekan.

b. Balok mortar dengan ukuran $12 \mathrm{~cm}$ $\mathrm{x} 3 \mathrm{~cm} \times 3 \mathrm{~cm}$ untuk pengujian kuat pukul dan kuat patah.

5. Talam untuk mencampur bahanbahan/material.

6. Kayu perojok.

7. Sendok semen/scrap.

8. Alat uji densitas, penyerapan air, kuat tekan, kuat patah, kuat pukul.

Untuk membuat sampel paving block mengacu pada standar mutu K 125 (125 $\mathrm{kg} / \mathrm{cm} 2)$ dengan komposisi semen : pasir : FAS $=1: 3: 0,6$.

\section{Perbandingan bahan-bahan yang} digunakan untuk membuat sampel

Tabel 1 Sampel dengan Tidak Menggunakan Polivinyl Alkohol pada Mould Berukuran $5 \mathrm{~cm} \times 5 \mathrm{~cm} \times 5 \mathrm{~cm}$, Semen $82 \mathrm{~g}$ dan Air $49 \mathrm{~g}$

\begin{tabular}{lll}
\hline \multicolumn{2}{l}{ Sampel } & Agregat \\
\hline & Pasir (\%) & Grit (\%) \\
\hline 1 & $100 \%=245,25 \mathrm{gr}$ & - \\
2 & $90 \%=220,72 \mathrm{gr}$ & $10 \%=24,52 \mathrm{gr}$ \\
3 & $80 \%=196,20 \mathrm{gr}$ & $20 \%=49,05 \mathrm{gr}$ \\
4 & $70 \%=171,67 \mathrm{gr}$ & $30 \%=73,56 \mathrm{gr}$ \\
5 & $60 \%=147,15 \mathrm{gr}$ & $40 \%=98,10 \mathrm{gr}$
\end{tabular}


Pembuatan Paving Block Berbasis Semen Polimer Dengan Limbah Padat Grit Sebagai Substitusi Pasir Dan Perekat Polivinyl Alkohol (Pva)

\begin{tabular}{clc}
\hline 6 & $50 \%=122,62 \mathrm{gr}$ & $50 \%=122,62 \mathrm{gr}$ \\
7 & $50 \%=122,62 \mathrm{gr}$ & $60 \%=147,15 \mathrm{gr}$ \\
8 & $30 \%=73,56 \mathrm{gr}$ & $70 \%=171,67 \mathrm{gr}$ \\
9 & $20 \%=49,05 \mathrm{gr}$ & $80 \%=196,20 \mathrm{gr}$ \\
10 & $10 \%=24,52 \mathrm{gr}$ & $90 \%=220,72 \mathrm{gr}$ \\
11 & $-=-$ & $100 \%=245,25 \mathrm{gr}$ \\
\hline
\end{tabular}

Sampel dengan Menggunakan

Polivinyl Alkohol pada Mould

Tabel 2.Berukuran $5 \mathrm{~cm}$ x $5 \mathrm{~cm}$ x 5 $\mathrm{cm}$, Semen $82 \mathrm{~g}$, Air $49 \mathrm{~g}$ dan PVA $6 \mathrm{~g}$

\begin{tabular}{lll}
\hline \multicolumn{2}{l}{ Sampel } & Agregat \\
\hline \multicolumn{2}{l}{ Pasir $(\%)$} & Grit $(\%)$ \\
\hline 12 & $100 \%=245,25 \mathrm{gr}$ & - \\
14 & $90 \%=220,72 \mathrm{gr}$ & $10 \%=24,52 \mathrm{gr}$ \\
15 & $70 \%=196,20 \mathrm{gr}$ & $20 \%=49,05 \mathrm{gr}$ \\
16 & $60 \%=147,15 \mathrm{gr}$ & $40 \%=98,10 \mathrm{gr}$ \\
17 & $50 \%=122,62 \mathrm{gr}$ & $50 \%=122,62 \mathrm{gr}$ \\
18 & $50 \%=122,62 \mathrm{gr}$ & $60 \%=147,15 \mathrm{gr}$ \\
19 & $30 \%=73,56 \mathrm{gr}$ & $70 \%=171,67 \mathrm{gr}$ \\
20 & $20 \%=49,05 \mathrm{gr}$ & $80 \%=196,20 \mathrm{gr}$ \\
21 & $10 \%=24,52 \mathrm{gr}$ & $90 \%=220,72 \mathrm{gr}$ \\
22 & $-=-$ & $100 \%=245,25 \mathrm{gr}$ \\
\hline
\end{tabular}

\section{Preparasi ( Pengolahan ) Bahan}

\section{A.Pengayakan Bahan}

a. Analisis ayakan pasir

Prinsip kerjanya adalah sebagai berikut :

1. Diambil bahan pasir yang telah dikeringkan di oven dengan suhu $(100 \pm 5)_{0} \mathrm{C}$.

2. Sampel pasir ditimbang sebanyak $500 \mathrm{~g}$.
3.Sampel pasir dimasukkan ke dalam ayakan yang telah disususesuadenganurutannya yaitu $\quad 9,52 \mathrm{~mm} ; \quad 4,76 \mathrm{~mm} ; \quad 2,38 \mathrm{~mm}$; $1,19 \mathrm{~mm} ; \quad 0,6 \mathrm{~mm} ; \quad 0,30 \mathrm{~mm} ; \quad 0,3 \mathrm{~mm}$; $0,15 \mathrm{~mm}$ dan pan.

4.Tutup susunan ayakan tersebut dan letakkan di Shieve Shaker Machine, kemudian dihidupkan selama 10 menit.

5.Setelah 10 menit ayakan diambil dan ditimbang sampel pasiryangtertahandimasing- masing ayakan tersebut.

6.Menghitung persentase berat sampelyangtertahanpadamasingmasingaya kanterhadap berat total sampel untuk menentukan persentase Modulus kehalusan (fine modulus) dari agregat yang digunakan.

b. Analisis berat jenis dan absorbsi pasir

Prinsip kerjanya adalah sebagai berikut :

1. Disediakan sampel pasir dalam kondisi kering permukaan sebanyak $500 \mathrm{~g}$

2.Sampel pasir dimasukkan ke dalam piknometer kemudian diisi air sampai penuh permukaan piknometer.

3. Piknometer yang berisi sampel pasir divakum sampai hilang gelembunggelembung udara.

4. Dimasukkan air ke dalam piknometer sampai 800 cc kemudian ditimbang (B). 
5.Kemudian ditambahkan air sebanyak 800 cc ke dalampiknometeryangtelahdivakum kemudian ditimbang $(\mathrm{C})$.

6. Kemudian sampel pasir dikeringkan sampai tidak ada kandungan air, lalu ditimbang (D).

c. Analisis ayakan grit

Prinsip kerja yaitu:

1. Diambil sampel grit yang telah kering di oven dengan suhu $(100 \pm 5)_{0} \mathrm{C}$.

2. Sampel grit ditimbang $500 \mathrm{~g}$.

3. Sampel grit dimasukkan ke dalam ayakan yang telahdisusunsesuaidenganurutannya yaitu $9,52 \mathrm{~mm} ; 4,76 \mathrm{~mm} ; 2,38 \mathrm{~mm} ; 1,19 \mathrm{~mm}$; 0,6mm; 0,30mm; 0,3mm; 0,15mm dan PAN.

4.Tutup susunan ayakan tersebut dan letakkan di Shieve Shaker Machine, kemudian dihidupkan selama 10 menit. 5 . Setelah 10 menit ayakan diambil dan ditimbang sampel grit yang tertahandimasing-masing ayakan tersebut.

6. Menghitung persentase beratsampelyangtertahanpadamasingmasi ngayakanterhadap berat total sampel untuk menentukan persentase Modulus kehalusan (fine modulus) dari agregat yang digunakan.

\section{Rumus Fine Modulus =}

\section{$\frac{\sum \text { kumulatif tertahan ayakan }}{100}$}

d. Analisis berat jenis dan absorbsi grit

1. Disediakan sampel grit dalam kondisi kering permukaan sebanyak 500 gr (A).
2. Sampel grit dimasukkan ke dalam piknometer kemudian diisi air ampai penuh permukaan piknometer.

3. Piknometer yang berisi sampel grit divakum sampai hilang gelembunggelembung udara.

4. Dimasukkan air ke dalam piknometer sampai $800 \mathrm{cc}$ kemudian ditimbang (B).

5. Kemudian ditambahkan air sebanyak800cckedalampiknometeryangtel ahdivakumkemudian ditimbang (C).

6. Kemudian sampel grit dikeringkan sampai tidak ada kandungan air,alu ditimbang (D).

Berat jenis grit dalam keadaan kering permukaan dapat dicari dengan rumus :

Berat jenis kering permukaan $=\frac{A}{B+A+C}$

Sedangkan absorbsi grit dapat dicari dengan

rumus :

$$
\% \text { absorbsi }=\frac{A-D}{D} \times 100 \%
$$

Selanjutnya masukkan PVA yang sudah dimixer homogen sampai menjadi bubur ke dalam adukan pasir, grit dan semen . Untuk 1 kali pengadukan serbuk PVA yang digunakansebanyak $6 \mathrm{~g}$.

\section{B. Pencampuran Bahan}

Bahan yang telah diayak dicampur dengan komposisi pada tabel 1 untuk mengetahui peranan grit sebagai subsitusi terhadap pasir dan pada tabel 2 untuk mengetahui peranan Polivinyl Alkohol sebagai perekat/penguat. 
Pembuatan Paving Block Berbasis Semen Polimer Dengan Limbah Padat Grit Sebagai Substitusi Pasir Dan Perekat Polivinyl Alkohol (Pva)

Untuk Sampel A ( tanpa PVA),komposisi campuran seperti tabl 1

a. Masukkan pasir, grit, semen ke dalam talam kemudian diaduk dengan sendoksemen sampai campuran merata.

b. Kemudian ditambah air ke dalam adukan, banyaknya air yang digunakan dalam 1 kali pengadukan dengan FAS 0,6 yang menurut teori FAS $=0,25-0,65$ (Tri Muliono, 2005).Didiamkan selama 4 menit kemudian diaduk sampai campuran homogen.

Untuk Sampel B (dengan PVA), komposisi campuran seperti tabel 2

a. Masukkan pasir, grit, semen ke dalam talam kemudian diaduk dengan sendok semen sampai campuran merata.

b. Kemudian ditambah air seperti proses sampel A.

c. Selanjutnya masukkan PVA yang sudah dimixer homogen sampai menjadi bubur ke dalam adukan pasir, grit dan semen.

Untuk 1 kali pengadukan bubuk PVA yang dibubur sebanyak $6 \mathrm{~g}$.

\section{Pembentukan atau Pencetakan Sampel}

1. Mould yang digunakan berukuran $5 \mathrm{~cm}$ $x 5 \mathrm{~cm} \quad \mathrm{x} 5 \mathrm{~cm}$ untuk sampel pengujiandensitas; penyerapan air, kuat tekan; berukuran $12 \mathrm{~cm} \times 3 \mathrm{~cm} \times 3 \mathrm{~cm}$ untuk sampel pengujian kuat pukul dan kuat patah.

2. Timbang bahan sesuai dengan komposisi yang sudah ditentukan.
3. Aduk sampai merata.

4. Masukkan kedalam mould setinggi $1 / 2 \mathrm{~h}$ lalu dipadatkan dengan alat perojok sebanyak 32 tumbukan.

5. Penuhkan mould dan padatkan lagi dengan alat perojok sebanyak 32 tumbukan.

6. Diisi lagi sampai padat dan ratakan permukaannya.

7. Dikeringkan di dalam mould selama 24 jam baru dikeluarkan.

8. Dilakukan proses perendaman secara alami selama 28 hari, kemudian dilakukan pengujian dari sampel.

D. Karakterisasi (Pengujian) Paving Block

Pengujian yang dilakukan dalam penelitian ini meliputi : densitas, penyerapan air, kuat tekan, kuat pukul dan kuat patah.

\section{Densitas (Density)}

Pengukuran densitas dari masingmasing komposisi paving block yang telah dibuat, diamati dengan menggunakan prinsip Archimedes dan mengacu pada standar ASTM C - $00-2005$

Prosedur pengukuran densitas :

1. Pada proses awal dilakukan penimbangan massa benda di udara (massa sampel kering $\mathrm{W}_{\mathrm{s}}$ ) dengan menggunakan neraca digital, dimana sampel kering ini telahmengalami proses pengeringan di atas drying oven selama 1 jam. Sampel yang diuji adalah kubus ukuran $5 \mathrm{~cm} \mathrm{x}$ $5 \mathrm{~cm} \times 5 \mathrm{~cm}$. 
2. Sampel yang telah ditimbang, kemudian direndam di dalam air selama 1 jam bertujuan untuk mengoptimalkan penetrasi air terhadap sampel. Setelah waktu penetrasi terpenuhi, seluruh permukaan sampel dilap dengan kain flanel dan dicatat massa sampel setelah direndam di dalam air, $\mathrm{W}_{\mathrm{b}}$.

3. Gantung sampel, pastikan tepat pada posisi tengah dan tidak menyentuh alas beker gelasyang berisi air, dimana massa sampel berikut penggantung di dalamair, $\mathrm{W}_{\mathrm{g} .} \rho$

4. Selanjutnya sampel dilepas dari kawat penggantung, dan memcatat massa kawatpenggantung, Wk.

Dengan mengetahui besaran-besaran tersebut di atas, maka nilai densitas paving block dapat dihitung dengan menggunakan persamaan ,Densitas $=\frac{W s}{W b-(W g-W k)} \times \rho$ air

\section{Penyerapan Air (Water Absorption)}

Untuk mengetahui besarnya penyerapan air dari paving block yang telah dibuat, maka perlu dilakukan pengujian yang mengacu pada standar ASTM C 20-00 -2005. Prosedur pengukuran penyerapan air :

1. Sampel yang telah direndam selama 28 hari ditimbang massanya dengan menggunakan neraca digital yang disebut dengan massa sampel kering, Mg. Sampel yang diuji adalah sampel kubus ukuran $5 \mathrm{~cm} \times 5 \mathrm{~cm} \times 5 \mathrm{~cm}$.
2. Kemudian sampel direndam di dalam air selama 1 jam sampai sampel ini jenuh dan disebut $\mathrm{Mj}$.

Dengan menggunakan persamaan $\mathrm{W} A=$ $\frac{M j M k}{M k} \times 100 \%$, maka nilai penyerapan air dari paving block dapat dihitung.

\section{Kuat Tekan (Compressive Strength)}

Untuk mengetahui besarnya kuat tekan dari sampel paving block yang telah dibuat,maka perlu dilakukan pengujian yang mengacu pada standar ASTM C 270-2004 dan ASTM C 780. Alat yang digunakan untuk menguji kuat tekan adalah Universal Testing Machine (UTM).

Prosedur pengujian kuat tekan adalah sebagai berikut :

1. Sampel kubus berukusan $5 \mathrm{~cm} \times 5 \mathrm{~cm} \times$ $5 \mathrm{~cm}$ dihitung luas permukaannya dengan $A=$ sisi $x$ sisi.

2. Sebelum pengujian berlangsung, alat ukur (gaya) terlebih dahulu dikalibrasi dengan jarum penunjuk tepat pada angka nol.

3. Kemudian tempatkan sampel tepat berada di tengah pada posisi pemberian gaya dan arahkan swtich on-off ke arah on, maka pembebanan secara otomatis akan bergerak dengan kecepatan konstan.

4. Apabila sampel telah pecah, arahkan switch ke arah off, maka motor penggerak akan berhenti. Kemudian catat besarnya gaya yang ditampilkan pada panel display. 
Pembuatan Paving Block Berbasis Semen Polimer Dengan Limbah Padat Grit Sebagai Substitusi Pasir Dan Perekat Polivinyl Alkohol (Pva)

Dengan menggunakan persamaan tekanan $\mathrm{P}$ $=\frac{F}{A} \quad$, nilai kuat tekan dari paving block dapat

dihitung.

\section{Kuat Pukul (Impact Strenght)}

Alat yang digunakan untuk mengukur kuat pukul adalah Impact Testing Machine dimana model sampel berbentuk balok dengan ukuran $12 \mathrm{~cm}$ x $3 \mathrm{~cm}$ x $3 \mathrm{~cm}$.

Prosedur pengujian kuat pukul adalah sebagai berikut:

1. Sampel berbentuk balok diukur tebal dan lebarnya, kemudian diukur lebar papan pemukul (swing) yang diayunkan ke sampel uji.

2. Sebelum pengujian berlangsung, alat ukur terlebih dahulu dikalibrasi dengan jarum penunjuk tepat pada angka nol.

3. Tempatkan sampel tepat berada di tengah swing yang diayunkan.

4. Lepaskan swing dan akan berayun ke bawah memukul sampel uji.

5. Catatlah besarnya energi yang ditujukkan oleh panel display pada saat sampel uji patah.

Dengan menggunakan persamaan $\mathrm{Kc}=\frac{A k}{S o}$, maka nilai kuat pukul dari paving block dapat dihitung.

\section{Kuat Patah (Flexural Strength)}

Alat yang digunakan untuk menguji kuat patah adalah Universal TestingMachine(UTM) dan hal ini mengacu pada ASTM C 133 - 97 dan ASTM C 348 2002. Model sampel uji adalah berbentuk balok dengan ukuran $12 \mathrm{~cm}$ x $3 \mathrm{~cm}$ x $3 \mathrm{~cm}$. Prosedur pengujian kuat patah adalah sebagai berikut:

1. Sampel berbentuk balok diukur lebar dan tingginya, kemudian atur jarak titik tumpu sebesar $10 \mathrm{~cm}$ sebagai dudukan sampel.

2. Atur pegangan suplay sebesar 40 volt, untuk menggerakkan motor kearah atas maupun bawah. Sebelum pengujian berlangsung alat ukur (gaya) terlebih dahulu dikalibrasi dengan jarum penunjuk tepat pada angka nol

3. Kemudian tempatkan sampel uji tepat berada di tengah pada posisi pemberian gaya, dan arahkan switch ON/OFF ke arah ON, maka pembebanan secara otomatis akan bergerak.

4. Apabila sampel uji telah patah, arahkan switch kearah OFF agar motor penggerak berhenti. Kemudian catat besar gaya yang ditampilkan pada panel display.

Dengan menggunakan persamaan kuat patah $=\frac{3 P L}{2 b h^{2}}$, maka nilai kuat patah dari paving block

dapat dihitung.

\section{HASIL DAN PEMBAHASAN}

Paving block yang telah dibuat adalah campuran dari pasir, grit, semen dengan FAS 0,6 dan Polivinyl Alkohol 
Pembuatan Paving Block Berbasis Semen Polimer Dengan Limbah Padat Grit Sebagai Substitusi Pasir Dan Perekat Polivinyl Alkohol (Pva)

(PVA) dan direndam secara alami selama 28 hari. Kemudian diuji sifat-sifatnya. Karakteristik paving block sangat ditentukan oleh komposisi pasir dan grit serta proses perendamannya. Untuk mengetahui karakteristiknya dilakukan pengujian yang meliputi pengujian fisisnya (densitas dan penyerapan air), pengujian mekanik (kuat tekan, kuat pukul, kuat patah)serta analisa mikro strukturnya menggunakan mikroskop optik

\section{Densitas (density)}

Perhitungan pengujian densitas sampel tanpa menggunakan Polivinyl Alkohol (PVA),massa kawat 51 g,sampel no. 2 pada tabel 1pada komposisi $90 \%$ pasir dan $10 \%$ grit.

$$
\begin{gathered}
\text { Densitas }=\frac{W s}{W b-(W g-W k)} \times \rho \text { air } \\
=\frac{235,02}{151,1-(164-51)} \times 1= \\
\frac{235,02}{138,1}=1,70 \mathrm{~g} / \mathrm{cm}^{3}
\end{gathered}
$$

Dengan cara yang sama diperoleh nilai densitas paving blok untuk komposisi pasir dan grit yang berbeda dan hasil pengukuran dan perhitungan pada tabel 3 dibawah ini :

Tabel 3 Pengujian Densitas Sampel Tanpa

\begin{tabular}{|c|c|c|c|c|c|}
\hline & \multirow{6}{*}{$\begin{array}{l}\text { Kom } \\
\text { posisi } \\
\text { bahan }\end{array}$} & Ma & $\mathrm{Ma}$ & Mass & \\
\hline & & ssa & ssa & $\mathrm{a}$ & Den \\
\hline & & Bas & Ker & Diga & sitas \\
\hline & & $\mathrm{ah}$ & ing & ntung & (gr/c \\
\hline & & $\mathrm{Wb}$ & Wk & $\mathrm{Wg}$ & $\left.\mathrm{m}^{3}\right)$ \\
\hline & & ( & (gr) & (gr) & \\
\hline
\end{tabular}
Menggunakan Polivinyl Alkohol (PVA), Massa Kawat $51 \mathrm{~g}$

\begin{tabular}{|c|c|c|c|c|c|c|}
\hline & $\begin{array}{c}\text { Pasir( } \\
\%)\end{array}$ & $\begin{array}{l}\text { Grit } \\
(\%)\end{array}$ & gr) & & & \\
\hline 1 & 100 & 0 & $\begin{array}{l}268 \\
, 02\end{array}$ & $\begin{array}{r}256 \\
, 47\end{array}$ & 176 & 1,79 \\
\hline 2 & 90 & 10 & $\begin{array}{c}251 \\
, 1\end{array}$ & $\begin{array}{r}235 \\
, 02\end{array}$ & 164 & 1,70 \\
\hline 3 & 80 & 20 & $\begin{array}{l}257 \\
, 42\end{array}$ & $\begin{array}{c}238 \\
, 30\end{array}$ & 166 & 1,67 \\
\hline 4 & 70 & 30 & $\begin{array}{c}250 \\
, 58\end{array}$ & $\begin{array}{r}233 \\
, 43\end{array}$ & 161 & 1,66 \\
\hline 5 & 60 & 40 & $\begin{array}{c}251 \\
, 00\end{array}$ & $\begin{array}{r}234 \\
, 53\end{array}$ & 160 & 1,65 \\
\hline 6 & 50 & 50 & $\begin{array}{c}247 \\
.23\end{array}$ & $\begin{array}{c}224 \\
, 06\end{array}$ & 159 & 1,61 \\
\hline 7 & 40 & 60 & $\begin{array}{c}233 \\
, 11\end{array}$ & $\begin{array}{r}210 \\
, 64\end{array}$ & 152 & 1,59 \\
\hline 8 & 30 & 70 & $\begin{array}{r}225 \\
, 97\end{array}$ & $\begin{array}{r}205 \\
, 45\end{array}$ & 146 & 1,57 \\
\hline 9 & 20 & 80 & $\begin{array}{r}235 \\
, 03\end{array}$ & $\begin{array}{r}215 \\
, 51\end{array}$ & 142 & 1,50 \\
\hline $\begin{array}{l}1 \\
0\end{array}$ & 10 & 90 & $\begin{array}{l}230 \\
, 23\end{array}$ & $\begin{array}{c}211 \\
, 50\end{array}$ & 143 & 1,53 \\
\hline $\begin{array}{l}1 \\
1\end{array}$ & 0 & 100 & $\begin{array}{c}225 \\
, 90\end{array}$ & $\begin{array}{r}201 \\
, 43\end{array}$ & 135 & 1,42 \\
\hline
\end{tabular}

gr)

Sehingga dapat dibuat grafik hasil pengukuran densitas paving block yang berbasis semen, pasir, grit seperti gambar 1

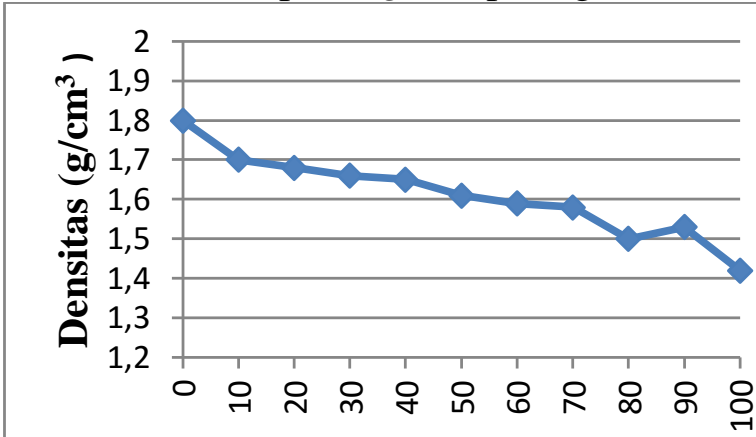
Komposisi Grit (\%)

Gambar 1. Grafik hubungan antara Densitas terhadap komposisi Grit tanpa PVA

Perhitungan pengujian Densitas sampel dengan menggunakan Polivinyl Alkohol (PVA),massa kawat 51 gr,untuk sampel no.2 
Pembuatan Paving Block Berbasis Semen Polimer Dengan Limbah Padat Grit Sebagai Substitusi Pasir Dan Perekat Polivinyl Alkohol (Pva)

pada tabel 4 ,pada komposisi $90 \%$ pasir dan $10 \%$ grit ,tanpa menggunakan PVA.

$$
\begin{aligned}
\text { Densitas } & =\frac{W s}{W b-(W g-W k)} \times \rho \text { air } \\
& =\frac{247,37}{257,82-(157-51)} \times 1 \mathrm{~g} /
\end{aligned}
$$

$\mathrm{cm}^{3}$

$$
=\frac{247,37}{151,82}=1,63 \mathrm{gr} / \mathrm{cm}^{3}
$$

Dengan cara yang sama diperoleh nilai densitas paving blok untuk komposisi pasir dan grit yang berbeda dan hasil pengukuran dan perhitungan dengan menggunakan

Polivinyl Alkohol

pada tabel 4 dibawah ini :

Tabel 4 Pengujian Densitas Sampel

Menggunakan Polivinyl Alkohol

(PVA), Massa Kawat $51 \mathrm{~g}$

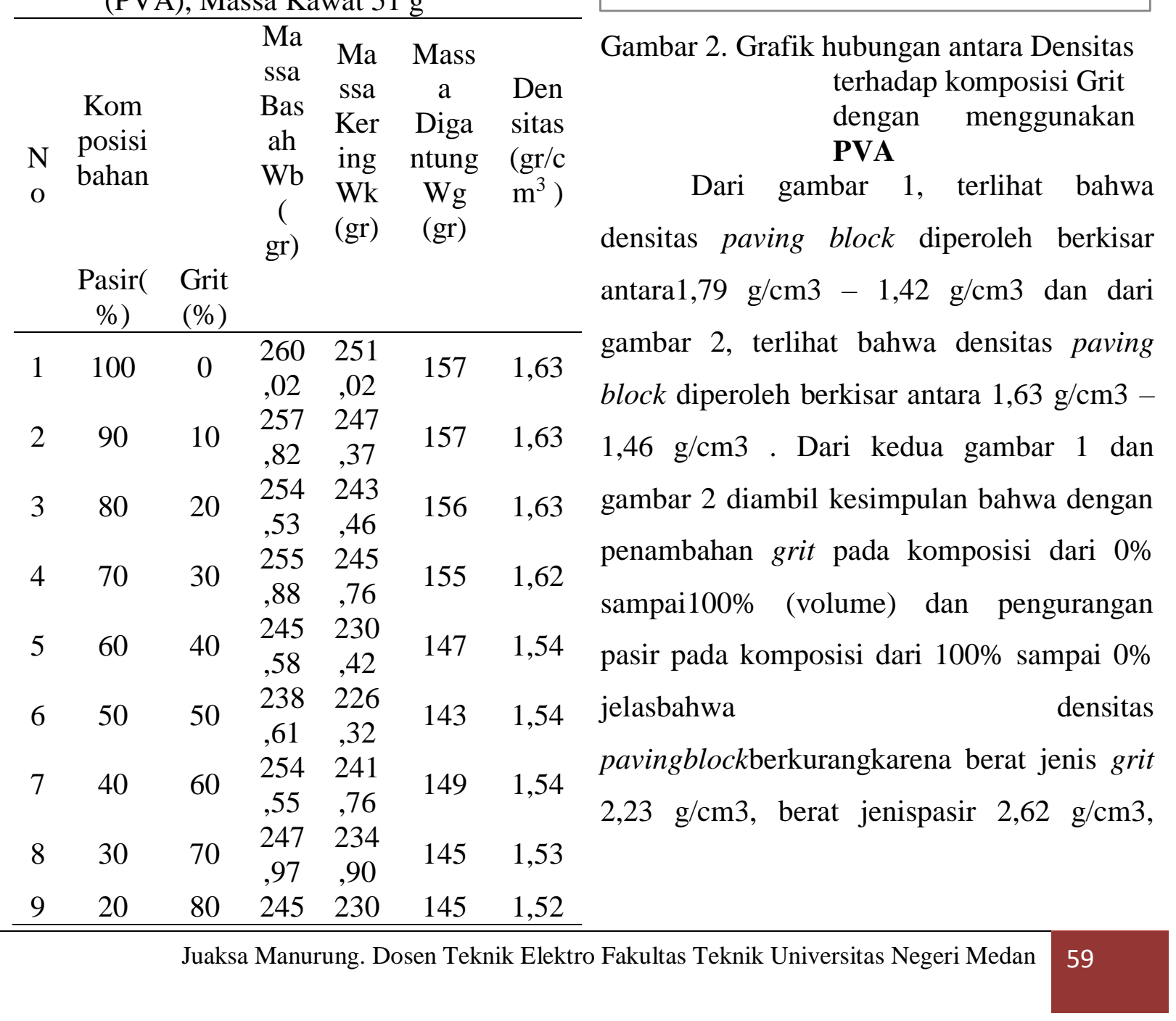

\begin{tabular}{rrrrrrr}
\hline & & &, 93 &, 80 & & \\
1 & \multirow{2}{*}{10} & 90 & 240 & 225 & & \\
0 & & &, 59 &, 12 & 140 & 1,49 \\
1 & \multirow{2}{*}{0} & & 229 & 214 & & \\
1 & 0 & 100 &, 07 &, 03 & 133 & 1,46 \\
\hline
\end{tabular}

Sehingga dapat dibuat grafik hasil pengukuran densitas paving block berbasis semen, pasir, grit dan PVA,seperti gambar 2, setelah direndam selama 28 hari secara alami

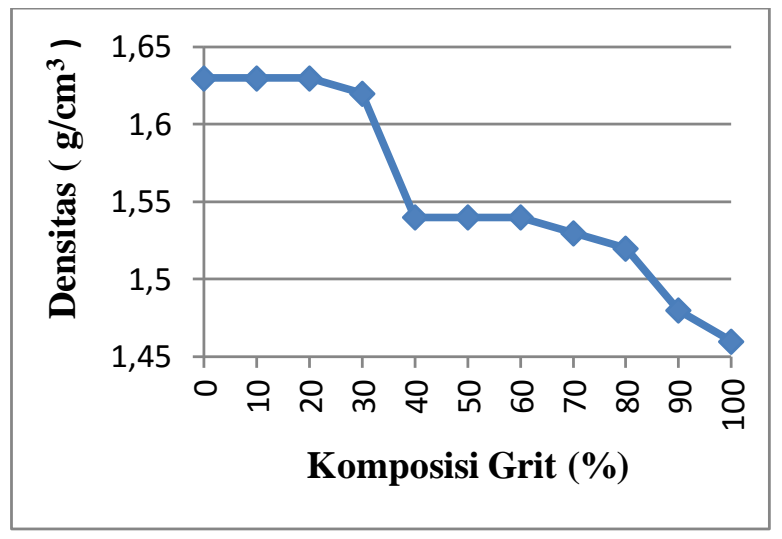
dengan menggunakan PVA 
Pembuatan Paving Block Berbasis Semen Polimer Dengan Limbah Padat Grit Sebagai Substitusi Pasir Dan Perekat Polivinyl Alkohol (Pva)

berat jenis PVA antara $1,19 \mathrm{~g} / \mathrm{cm} 3$ sampai $1,3 \mathrm{~g} / \mathrm{cm} 3$ dan berat jenis semen $3,10 \mathrm{~g} / \mathrm{cm} 3$.

\section{Penyerapan Air ( Water Absorption)}

Hasil pengukuran pengerapan air dari paving block yang berbasis semen, pasir, grit ditunjukkan pada gambar 3, dengan variasi komposisi $0-100 \%$ (volume grit), terlihat diperoleh $4,50 \%-12,15 \%$.

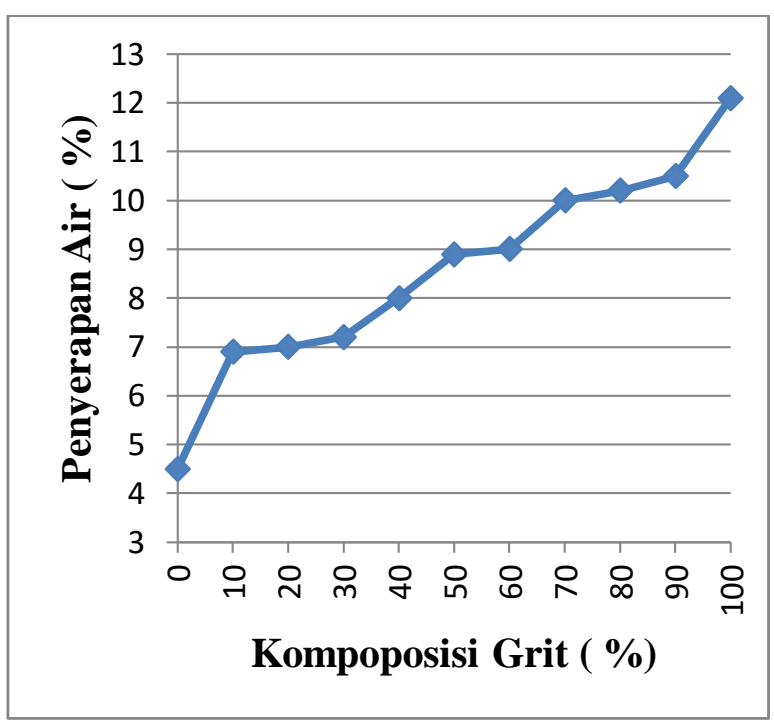

Gambar 3..Grafik hubungan antara penyerapan air terhadap komposisi grit tanpa menggunakan PVA

Hasil pengukuran penyerapan air dari paving block yang berbasis semen, pasir, grit, PVA (diperlihatkan pada gambar 4 ) dengan variasi komposisi $0-100 \%$ volume grit terlihat diperoleh $3,59 \%-7,03 \%$

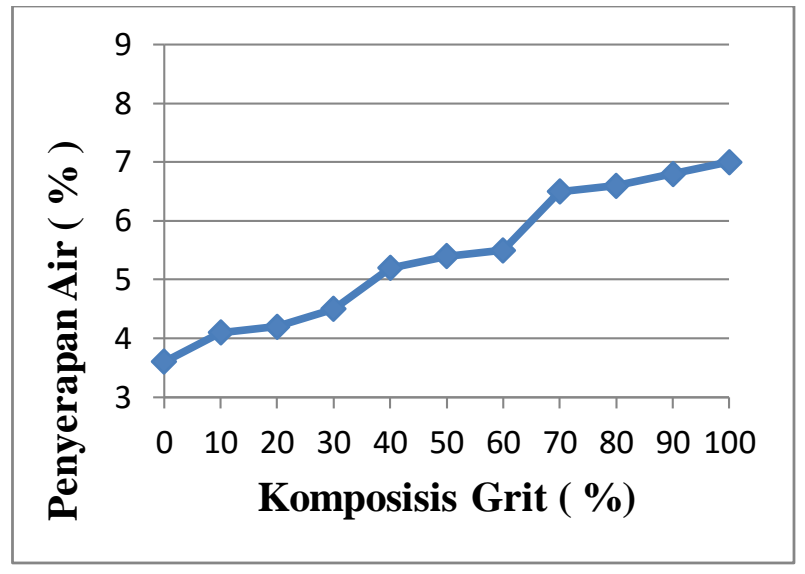

Gambar 4. Grafik hubungan antara penyerapan air terhadap komposisi grit menggunakan PVA

Dari gambar 3 dan 4 dapat diambil kesimpulan bahwa dengan penambahangritpadakomposisi dari $0 \%$ sampai $100 \%$ (volume) dan pengurangan pasir pada komposisi dari $100 \%$ sampai $0 \%$ (volume) diperoleh persentasepenyerapan air bertambah karena dari hasil analisis penyerapan air untuk agregat halus ( ASTMC-566-89 ) untuk material pasir sebesar 2,04 \% dan untuk material grit sebesar 3,72 \%. Sedangkan Polivinyl Alkohol sendiri mempunyai sifat basa dengan rantai $\mathrm{OH}$ dan larut dalam air. Seperti pada limbah grit dengan PH dalam air 12,73 yang bersifat basa maka PVA ini langsung mengikat.

\section{Kuat Tekan ( Compressive Strength)}

Hasil pengukuran kuat tekan dari paving block yang berbasis semen, pasir, grit, ditunjukkan pada gambar 5 dengan variasi komposisi: 0 - $100 \%$ (volume) grit, terlihat diperoleh berkisar antara 13,90 $\mathrm{MPa}-10,50$ MPa. 


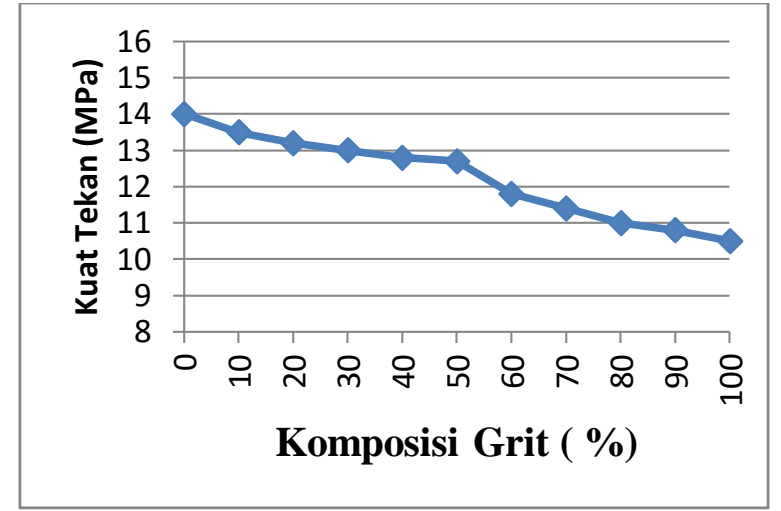

Gambar 5 Grafik hubungan antara kuat tekan terhadap komposisi grit tanpa menggunakan PVA

Hasil pengukuran kuat tekan paving block yang berbasis semen, pasir, grit, PVA ditunjukkan pada gambar 6 dengan variasi komposisi: $0-100 \%$ (volume) grit, terlihatdiperolehberkisar antara $15,20 \mathrm{MPa}-$

\section{1,80 Mpa}

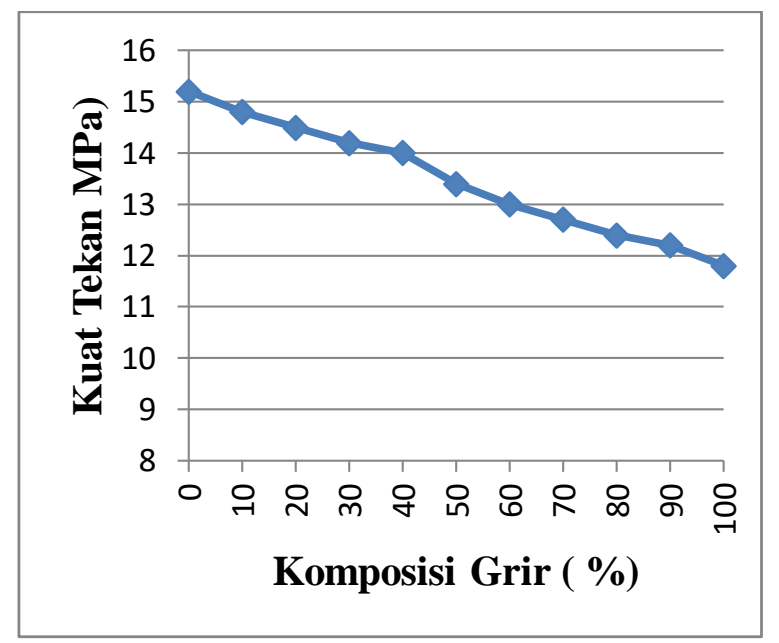

Gambar 6.Grafik hubungan antara kuat tekan terhadap komposisi grit menggunakan PVA

Dari gambar 5 dan 6(dari kedua grafik) dapat diambil kesimpulan bahwadengan penambahan grit pada komposisi dari $0 \%$ sampai $100 \%$ (volume) dan pengurangan pasir dari komposisi dari 100\% sampai $0 \%$ (volume), penyerapan air semakin besar karena daya serap air dari grit 3,72 \% dan daya serap air dari pasir 2,04\% dengan demikian semen akan semakin kekurangan air dalam campuran. Sifat semen sendiri adalah dapat berhidrasi bila terdapat air (semen mengikat karena reaksi hidrasi kimia yang melepaskan panas). Sedangkan menurut SNI 03-0611-1996 paving block yang digunakan sebagai standart mutu adalah $\mathrm{K}$ $125(125 \mathrm{~kg} / \mathrm{cm} 2)$, artinya penambahan grit optimum yang diperkenankan sebagai pengisi sebanyak $50 \%$ volume yang dalam hal ini dapat mengurangi pemakaian pasir maksimum $50 \%$ (volume).

Dengan

penambahan

PolivinylAlkohol(PVA)padakomposisicampu ranmakakuattekansemakin besar karena penggunaan PVA adalah perekat.

\section{Kuat Pukul (Impact Strength)}

Hasil pengukuran kuat pukul dari paving block yang berbasis semen, pasir, grit ditunjukkan pada gambar 7 dengan variasi komposisi: 0 - $100 \%$ (volume) grit terlihat diperoleh 3,41 MPa-0,52 MPa.

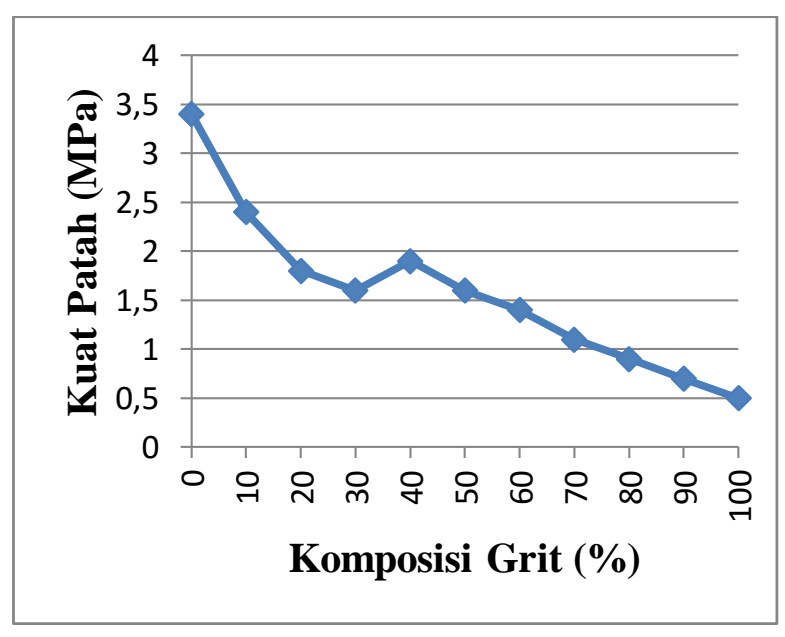


Pembuatan Paving Block Berbasis Semen Polimer Dengan Limbah Padat Grit Sebagai Substitusi Pasir Dan Perekat Polivinyl Alkohol (Pva)

Gambar 7.Grafik hubungan antara kuat pukul terhadap komposisi grit tanpa menggunakan PVA

Hasil pengukuran kuat pukul dari paving block yang berbasis semen, pasir, grit, Polivynil Alkohol (PVA) ditunjukkan pada gambar 8, dengan variasi komposisi : 0 - 100 $\%$ (volume) grit terlihat diperoleh 5,19 $\mathrm{MPa}$ $-0,89 \mathrm{MPa}$.

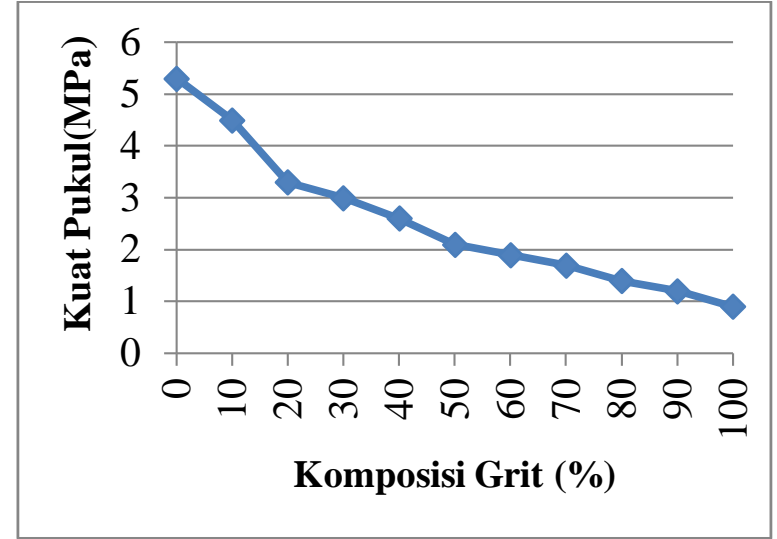

Gambar 8. Grafik hubungan antara kuat pukul terhadap komposisi grit menggunakan PVA

Dari gambar 7 dan 8 (kedua grafik) dapatdiambilkesimpulandengansemakinberta mbahnya pemakaian grit $0 \%$ sampai $100 \%$ (volume) dan berkurangnya pemakaian pasir $100 \%$ sampai $0 \%$ (volume) pada campuran maka kuat pukul paving block berkurang karena penyerapan air yang semakin besar dimanagrit 3,72\% dan pasir 2,04\% sehingga akanmengurangikebutuhan air untuk semen. Dalam hal ini semen mengikat karena adanya air (proses hidrasi pada semen). Dengan penambahan Polivinyl Alkohol (PVA) maka kuat pukul lebih besar dibandingkan dengan sampel tanpa menggunakan PVA karena
PVA bersifat sebagai perekat yang memperkuat ikatan antara material pasir, grit dan semen.

\section{Kuat Patah (Flexural Strength)}

Hasil pengukuran kuat patah dari paving block yang berbasis semen, pasir,grit ditunjukkan pada gambar 9,dengan variasi komposisi: 0 - $100 \%$ (volume) grit terlihat diperoleh 2,44 MPa-0,28 MPa.

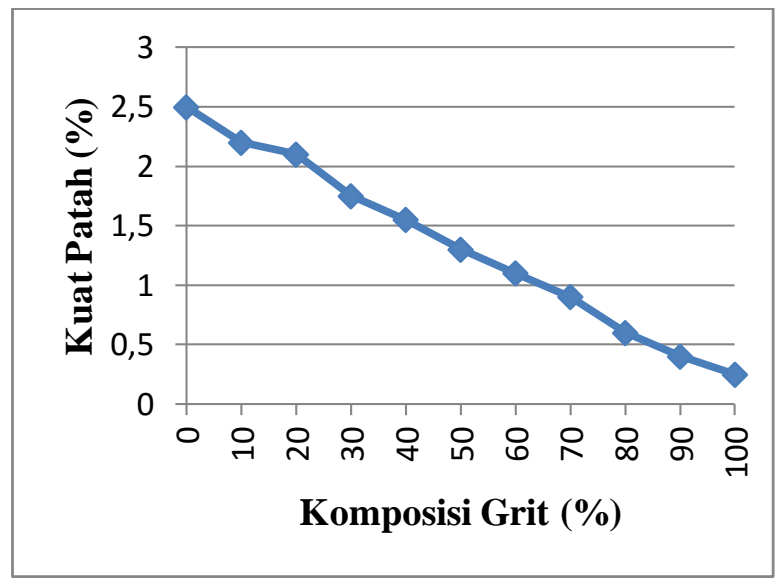

Gambar 9. Grafik hubungan antara kuat patah terhadap komposisi grit tanpa menggunakan PVA

Hasil pengukuran kuat pukul dari paving block

yangberbasissemen,pasir, grit,polivynilalkoho 1 (PVA) ditunjukkan pada gambar 10, dengan variasi komposisi : $0-100 \%$ (volume) grit terlihat diperoleh 3,89 $\mathrm{MPa}-1,39 \mathrm{MPa}$.

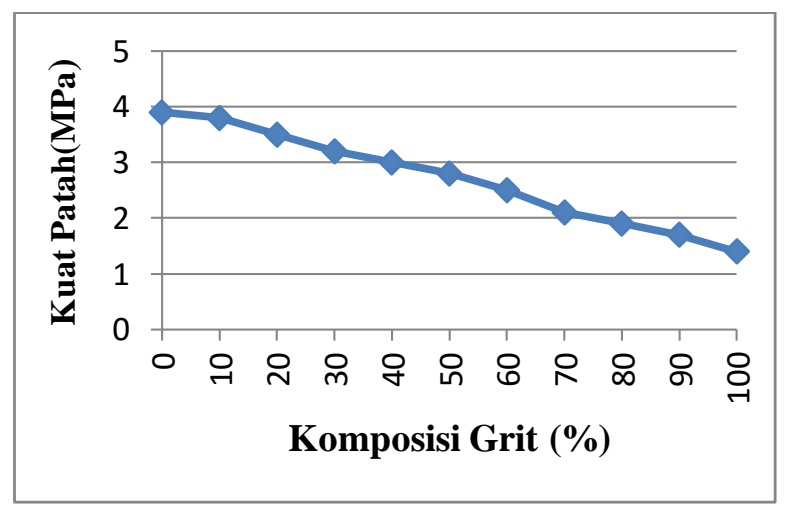


Pembuatan Paving Block Berbasis Semen Polimer Dengan Limbah Padat Grit Sebagai Substitusi Pasir Dan Perekat Polivinyl Alkohol (Pva)

Gambar 10.Grafik hubungan antara kuat patah terhadap komposisi grit menggunakan PVA

Dari gambar 9 dan 10( kedua grafik) dapat diambil kesimpulan bahwasampel paving block mempunyai kekuatan patah yang sangat kecil karena campuranadalah mortar yang agregatnya adalah pasir dan grit meski campuran semennyasempurna. Berbeda dengan besi cor yang merupakan salah satu jenis logam yangikatan antara materialnya sangatkuatsehingga mempunyai kuat patah yang besar.

\section{Pengamatan mikrostruktur sampel}

\section{dengan menggunakan mikroskop optik}

Analisa yang dilakukan adalah mengamati sampel dengan menggunakan PVApada komposisi grit banding pasir adalah 20 : 80 (\%volume).Mula-mula sampel diamati sebelum direndam di dalam air terlihat bahwa grit merupakan gumpulan yang berwarna putih kekuningan dan yang berwarna hitam adalah pasir seperti ditunjukkan gambar 11,12,13 dan 14 dibawah ini:

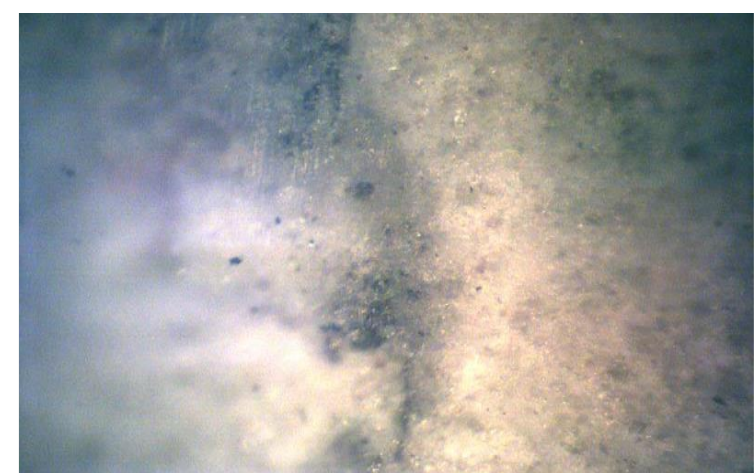

Gambar 11. Sampel sebel mikroskop optik dengan pembesaran
$200 \mathrm{x}$

menggunakan optik.

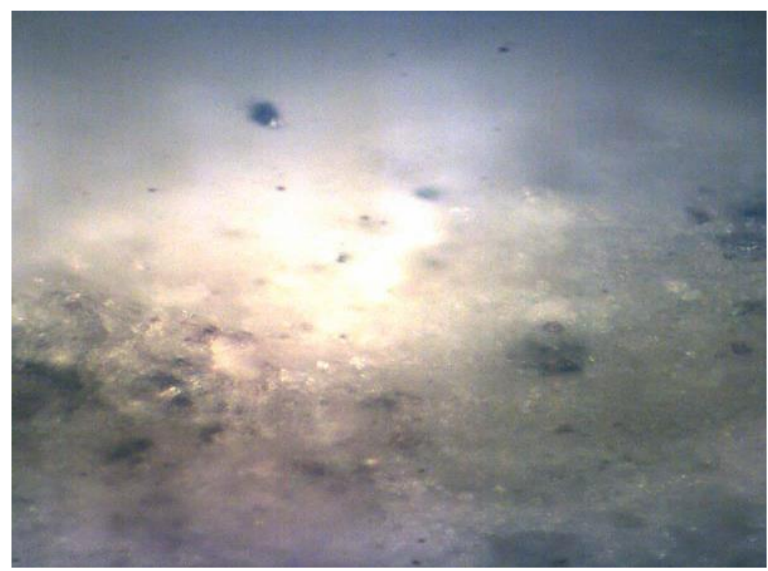

Gambar 12.Sampel sebelum direndam dengan perbesaran $500 \mathrm{x}$ menggunakan mikroskop 0ptik

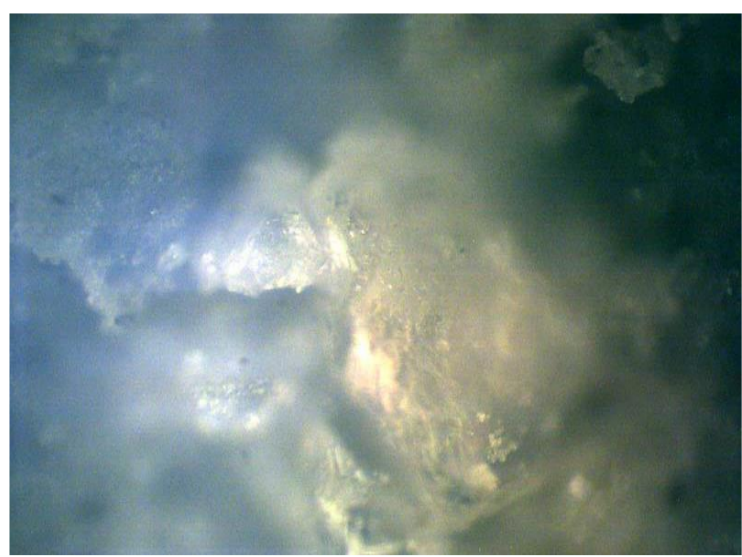

Gambar 13 ,Sampel setelah dierndam dengan pembesaran $500 \quad \mathrm{x}$ menggunakan mikroskope optik

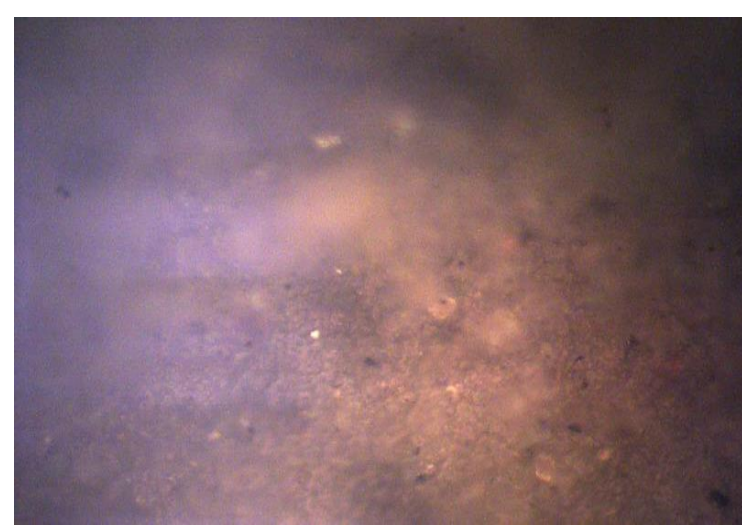


Pembuatan Paving Block Berbasis Semen Polimer Dengan Limbah Padat Grit Sebagai Substitusi Pasir Dan Perekat Polivinyl Alkohol (Pva)

Gambar 14.Sampel setelah direncanakan dengan pembesaran 500 x menggunakan mikroskop optik.

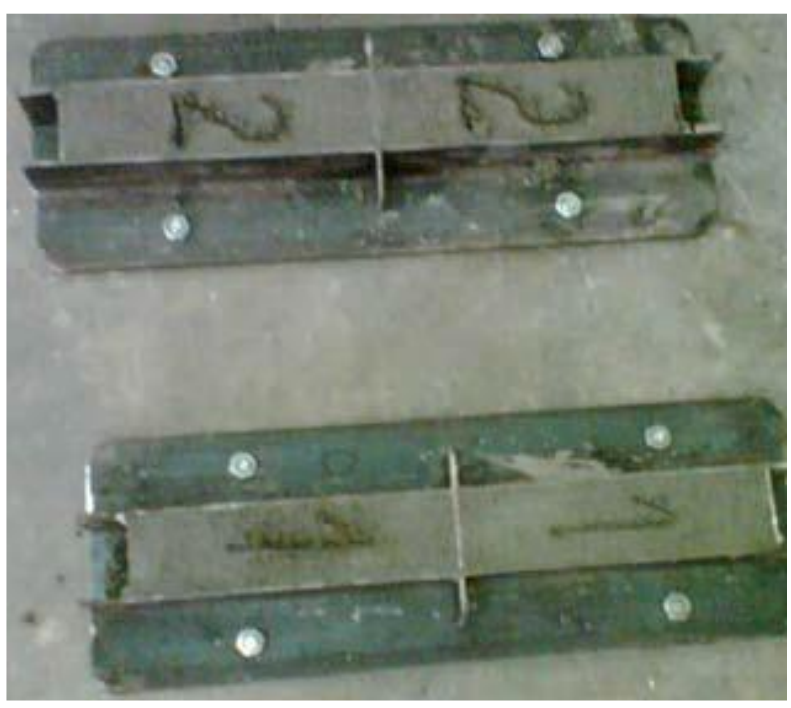

Gambar 15.Sampel berbentuk balok ,ukuran $12 \mathrm{~cm} \mathrm{x} 3 \mathrm{~cm} \mathrm{x} 3 \mathrm{~cm}$
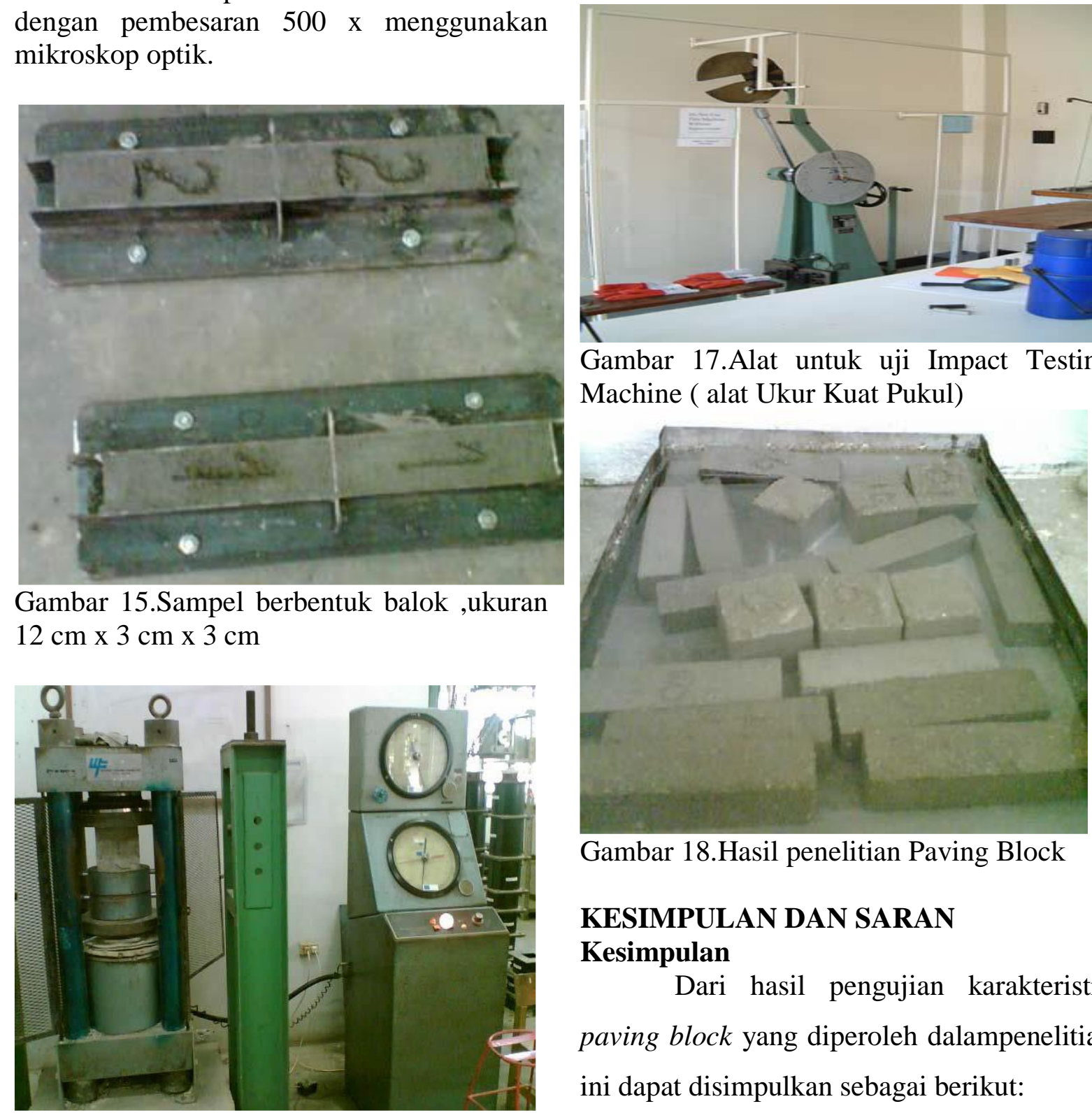

Gambar 17.Alat untuk uji Impact Testing Machine ( alat Ukur Kuat Pukul)

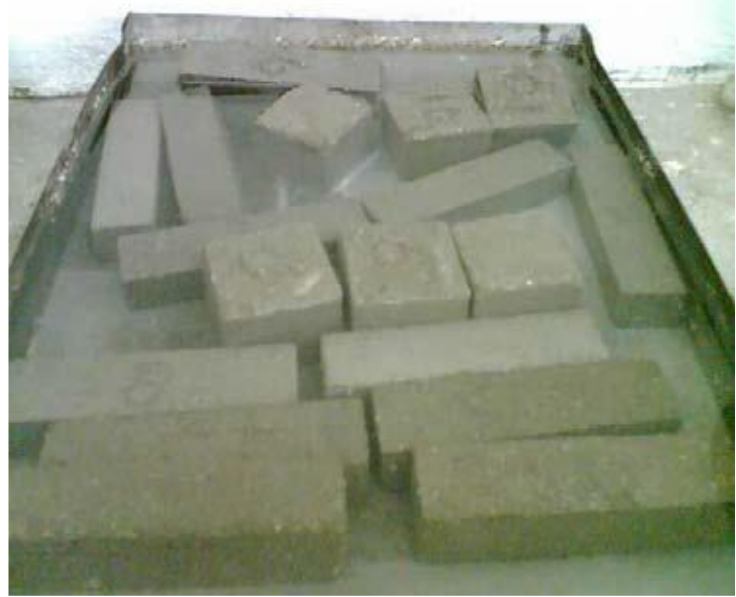

Gambar 18.Hasil penelitian Paving Block

\section{KESIMPULAN DAN SARAN Kesimpulan}

Dari hasil pengujian karakteristik paving block yang diperoleh dalampenelitian ini dapat disimpulkan sebagai berikut:

Gambar 16.Alat untuk uji kuat tekan

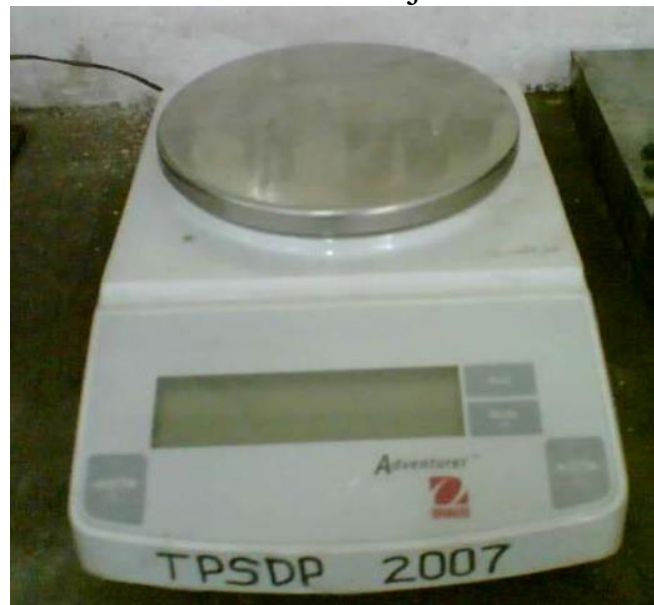

1. Pemakaian limbah padat industri pulp, antara lain grit dapat digunakan untukpembuatan paving block sebagai substitusi pasir dengan tujuan mengurangi penggunaan pasir.

2.Darihasilpengujiandiperolehkomposisiterba ikadalah50\% gritdan50\%pasir(\%volume)d engan karakteristik sebagai berikut: Paving block tanpapenggunaan PVA : densitas $=1,6 \mathrm{~g} / \mathrm{cm} 3$, serapan air $=8,86 \%$;

Gambar 18.Neraca digital 
Pembuatan Paving Block Berbasis Semen Polimer Dengan Limbah Padat Grit Sebagai Substitusi Pasir Dan Perekat Polivinyl Alkohol (Pva)

kuat tekan $=12,60 \mathrm{MPa}$; kuat pukul $=1,26$ MPa; kuat patah $=0,0133 \mathrm{MPa}$. Paving blockdengan menggunakan PVA sebagai berikut densitas $=1,54 \mathrm{~g} / \mathrm{cm} 3$, serapan air $=5,43 \%$; kuat tekan $=13,40 \mathrm{MPa}$; kuat pukul = 2,15 $\mathrm{MPa}$; kuat patah $=0,0278$ MPa.

3. Limbah padat grit dapat digunakan sebagai substitusi pasir karena :

a. Kandungan $\mathrm{SiO}_{2}=56,42 \%$

b. Bentuk butirannya bulat $=57 \%$

c. Kandungan organiknya kecil $=0,53 \%$

d. Densitas grit $=2,32 \mathrm{~g} / \mathrm{cm}_{3}$ dan densitas pasir $=2,62 \mathrm{~g} / \mathrm{cm}_{3}$

4.Darihasilphotomikroskopoptikterlihatbahw agumpalanmaterialgritberwarnaputihkeku ningan nampak lebih besar setelah bahan uji direndamdalam air

5.Paving block berbasis semen polimer $\begin{array}{llll}\text { dengan standard } & \mathrm{K} & 125\end{array}$ digunakanuntukmemperindah trotoar jalan atau taman pekarangan dan halaman rumah,bukan digunakan pada areal khusus seperti pada pelabuhan peti kemas,terminal dan bandar udara.

\section{Saran}

1. Untuk melengkapi penelitian paving block berbasis semen ini perlu dilakukanpengkajian lebih lanjut tentang tekno ekonominya karena harga polivynil alkohol yang sangat mahal.

2. Perlu dilakukan pencampuran grit dan sampel semenkarenadarihasilkarakteristik grit kandungan $\mathrm{SiO}_{2}=56,42 \%$ dan semen merupakan campuran Silikat Kalsium $\left(\mathrm{Ca}_{2} \mathrm{SiO}_{4}\right)$, untuk melihat adakah ikatan antara kedua agregat tersebut.

\section{DAFTAR PUSTAKA}

American Society for Testing and Material C-566-1989 (Standard pengujian berat dan grit) jenis dan absorbsi dari agregat pasir

American Society for Testing and Material C-136-1993 (Standard pengujian lolos saringan atau Sieve Analysis dari agregat pasir dan grit)

American Society for Testing and Material C-133-1997 dan C-348-2002 (Standard pengujian kuat patah benda uji)

American Society for Testing and Material C-270-2004 dan C-780 (Standard kuat tekan benda uji dengan menggunakan Universal Testing Machine UTM)

American Society for Testing and Material C-00-2005 (Standard pengujian densitas benda uji)

American Society for Testing and Material C-20-2005 (Standard pengujian penyerapan air benda uji)

Standard Nasional Indonesia, SNI-1691-1996 (Standard campuran semen, pasir dan FAS pada pembuatan paving block)

Ferdinand L. Singer and Andrew Pytel,1985

Kekuatan Bahan, edisi ketiga, Erlangga, Jakarta

Jacob and Kilduff, 2005 Engineering

Materials Technology, Pearson Prentice Hall, 5 
Pembuatan Paving Block Berbasis Semen Polimer Dengan Limbah Padat Grit Sebagai Substitusi Pasir Dan Perekat Polivinyl Alkohol (Pva)

Lawrence H. Van Vlack,1991 Ilmu dan

Teknologi Bahan, edisi kedua, Erlangga, Jakarta

Malcohn R.S, 2001, Kimia Polimer, edisi pertama, Pradnya Paramita, Jakarta

M. Zambrano, V. Parodi, J. Baeza, G. Vidal 2007 Acids Soils PH and Nutrient Improment when Amended with Inorganic Solic Waste From Kraft Mill. Journal of the Chilean Chemical

Society, page 4 e-mail:gividal@Udec.cl

Meyer, Fred W.Bill Jr, 1984, Tex book of Polymer Science. Third Edition, Jhon Wiley $\&$ Son, New York

Shinroku Saito,1985, Pengetahuan Bahan

Tehnik, Edisi pertama, Pradnya Paramita, Jakarta 1971. Peraturan Beton Bertulang Indonesia. Departemen Pekerjaan Umum, Bandung 